\title{
ВЫДЕЛЕНИЕ ВИРУСА БОЛЕЗНИ ШМАЛЛЕНБЕРГА У ИМПОРТИРУЕМОГО СКОТА НА ТЕРРИТОРИИ РОССИЙСКОЙ ФЕДЕРАЦИИ
}

\author{
О.Г. ГУБЕНКО, О.П. БЬЯДОВСКАЯ, А.В. СПРЫГИН, С.В. КОНОНОВА, \\ А.В. ПИСКУНОВ, А.В. КОНОНОВ
}

Болезнь, вызванная вирусом Шмалленберга (Schmallenberg virus), - это трансмиссивная арбовирусная инфекция, поражающая крупный рогатый скот (КРС), овец и коз всех возрастных групा, которая в случае массового распространения приводит к значительным экономическим потерям. На территории Российской Федерации специфические антитела против возбудителя болезни Шмалленберга (БШ) впервые выявлены в апреле 2013 и 2014 годов в Андреапольском и Конаковском районах Тверской области в рамках эпизоотического мониторинга при исследовании сыворотки крови от крупного рогатого скота. В октябре 2014 года в одном из хозяйств Новосокольнического района Псковской области в крови КРС обнаружены специфические антитела к БШ. Представляемая работа впервые обобщает результаты мониторинговых исследований по БШ в России с 2014 по 2016 год. Проведенный серологический мониторинг БШ показал большой процент серопозитивного местного скота в Калининградской, Псковской и Воронежской областях, в районах, граничащих со странами ЕС, а также среди скота, импортированного на территорию России из таких стран как Франция, Швеция, Дания, Польша, что указывает на необходимость дальнейшего сероконтроля. Впервые сообщается о выявлении в 2016 году ПЦР-позитивных животных, импортируемых из ЕС, и, что очень важно, об обнаружении в 2015 и 2016 годах сероконверсии к вирусу болезни Шмалленберга у КРС, рожденного и выращенного в Калининградской и Псковской областях Российской Федераци, которые граничат с неблагополучными по БШ странами ЕС. В каждой из областей сероконверсию наблюдали в 5 районах. Полученные данные свидетельствуют о возможном распространении вируса БШ на территории России. Выделение возбудителя БШ от импортного скота, ввезенного из Германии в Калининградскую область, в культуре клеток Vero и последующее секвенирование фрагмента гена из сегмента $\mathrm{S}$ показали, что этот вирус обладает 100 \% гомологией с вирусом БШ, обнаруженным в странах Северной Европы в 2012 году.

Ключевые слова: вирус болезни Шмалленберга, перевиваемая культура клеток Vero, полимеразная цепная реакция (ПЦР), филогенетический анализ, секвенирование.

Болезнь, вызванная вирусом Шмалленберга (Schmallenberg virus), была первоначально зарегистрирована в Северной Рейн-Вестфалии (Германия) и на северо-западе Нидерландов. Это трансмиссивная арбовирусная инфекция крупного рогатого скота (КРC), овец и коз всех возрастных групп, характеризующаяся лихорадкой, истощением и снижением удоев. Отличительная особенность заболевания в том, что заражение животных на стадии стельности приводит к абортам и мертворождениям, что влечет за собой значительные экономические потери в случае массового распространения инфекции (1).

Возбудитель БШ принадлежит к семейству Буньявирусы (Bunyaviridae), роду Ортобуньявирусы (Orthobunyavirus), серогруппе Симбу (Simbu serogroup). Вирус БШ имеет геном, состоящий из сегментов $\mathrm{S}$ (короткий), M (средний) и L (длинный), и представлен одноцепочечной $\operatorname{PHK}(1,2)$. Инкубационный период заболевания - от 1 до 4 сут, виремия длится от 1 до 5 сут. После экспериментального заражения овец и коз клиническая картина появляется на 3-и-5-е сут (3). У инфицированных плодов вирус в первую очередь обнаруживается в головном мозге. У больных животных вирус может быть выделен из крови. При молекулярных исследованиях геном вируса БШ может быть обнаружен в крови, органах инфицированных плодов, плаценте, амниотической жидкости и меконии (4).

Вирус БШ передается трансмиссивно через кровососущих насекомых, которые распространены по всей территории Российской Федера- 
ции (5). Значение переносчиков болезни Шмалленберга в агроклиматических условиях Россия (с учетом выявленного биоразнообразия мокрецов) освещена в обзоре А.В. Спрыгина и соавт. (6). Важную роль в заражении животных играет сезон года, в зависимости от которого изменяется численность кровососущих насекомых. Главные биологические переносчики вируса БШ - мокрецы рода Culicoides (семейство Ceratopogonidae), одни из самых мелких кровососущих двукрылых насекомых гнуса (5). Установлено, что вирус реплицируется в слюнных железах самок мокрецов в течение 4-16 сут в зависимости от температуры окружающей среды и влажности $(3,7)$. Ранее энтомологические исследования показали, что вирус БШ выявлен в пулах мокрецов (Culicoides obsoletus, C. dewulfi, C. pulicaris, C. punctatus), отобранных на территории ряда стран Европы (Дания, Норвегия, Нидерланды, Германия, Бельгия, Италия и Польша) (8-11). Известно, что вирус БШ передается при укусах других кровососущих, в том числе комаров семейства Culicidae $(12,13)$. В настоящее время доказана вертикальная передача вируса через плаценту, при этом прямая передача маловероятна. Кроме этого, вирус БШ обнаруживается в сперме и эмбрионах, полученных от зараженного скота (14). Более подробно свойства вируса БШ описаны в обзоре А.В. Спрыгина и соавт. (7).

Характерная эпидемиологическая особенность вируса БШ - высокая межстадная и низкая внутристадная превалентность. Исследования, проведенные с июня по сентябрь 2016 года на поголовье овец из Бельгии, показали значительный рост общей (от 25 до 62 \%) и межстадной (от 60 до $96 \%$ ) серопревалентности по вирусу БШ, что указывает на наиболее широкомасштабную рециркуляцию этого возбудителя с момента его первого появления в 2011 году. Циркуляция вируса БШ подтверждена выявлением РНК вируса в пулах мокрецов Culicoides obsoletus, coбранных в районе Антверпена (Бельгия) в августе 2016 года, причем минимальный уровень заболеваемости самих животных достигал $3 \%$ (15).

Вспышки БШ регистрировали в 2012-2014 годах в странах ЕС (Нидерланды, Германия, Бельгия, Англия, Франция, Италия, Испания, Дания, Люксембург, Швейцария, Швеция, Австрия, Польша, Финляндия, Ирландия, Норвегия, Греция, Словения, Латвия и др.) $(15,16)$. В течение 2011-2012 годов на территории России проводился мониторинг импортированных и местных животных, который не выявил антитела к вирусу БШ у местного скота (17). Впервые на территории РФ специфические антитела против возбудителя БШ обнаружили в апреле 2013 и 2014 года в Андреапольском и Конаковском районах Тверской области при исследовании сыворотки крови от крупного рогатого скота в рамках эпизоотического мониторинга $(18,19)$. В октябре 2014 года в одном из хозяйств Новосокольнического района Псковской области в крови крупного рогатого скота были также обнаружены специфические антитела к вирусу БШ (20).

Болезнь Шмалленберга диагностируют на основании клинических признаков и обнаружения вирусного генома методом ПЦР в реальном времени (21), а также выделения вируса в культурах клеток насекомых (КС), почки сирийского хомячка (ВНК), почки африканской зеленой мартышки (Vero) или его выявления (как родственного вирусу болезни Акабане) при интрацеребральном заражении мышей-сосунов. Вирус БШ может быть выделен из крови зараженных взрослых животных, а также из различных тканей инфицированного плода, в частности из мозгового биоматериала (22). Для серологической диагностики применяют иммуноферментный анализ (ИФА), непрямую иммунофлуоресценцию, реакцию нейтрализации вируса (23). 
Недостаточная изученность возбудителя БШ, а также отсутствие конкретных данных о его переносчиках на территории России стимулируют мониторинговые исследования как выращенного на территории РФ скота, так и животных, импортируемых из ЕС.

В представляемой публикации мы впервые обобщаем результаты мониторинговых исследований по БШ, проведенных в России с 2014 по 2016 год. Также впервые описано выявление в 2016 году ПЦР-позитивных животных, импортируемых из ЕС, и об обнаружении в 2015 и 2016 годах сероконверсии к вирусу болезни Шмалленберга у крупного рогатого скота, рожденного и выращенного в регионах России, которые граничат с неблагополучными по БШ странами ЕС.

Цель нашей работы - мониторинговые молекулярно-биологические исследования проб сыворотки крови и крови от импортного и аборигенного крупного рогатого скота на наличие вируса болезни Шмалленберга.

Методика. Использовали пробы стабилизированной крови и сыворотки от карантинного скота (телки), ввезенного из стран ЕС на территорию России, а также от местного скота. Всего исследовали 33542 пробы стабилизированной крови и 16749 проб сыворотки крови животных из Воронежской, Владимирской, Калужской, Брянской, Рязанской, Ростовской, Кировской, Калининградской, Ленинградской, Ивановской, Кировской, Тюменской, Ростовской, Екатеринбургской, Вологодской, Московской, Псковской, Смоленской, Волгоградской, Тверской, Липецкой, Свердловской, Новосибирской, Тульской, Нижегородской, Курской областей, Алтайского края, Красноярского края, Карачаево-Черкесской Республики, Республики Башкортостан, Республики Крым, Чувашской Республики, Республики Дагестан, Республики Татарстан, из Республики Таджикистана, а также из стран ЕС - Франции, Германии, Венгрии, Австрии, Польши, Дании, Нидерландов, Чехии, Словакии, Финляндии. Все пробы были получены в период с 2014 по 2017 год.

Антитела к вирусу БШ выявляли в сыворотках крови КРС с помощью коммерческого набора ID Screen ${ }^{\circledR}$ Capripox Double Antigen Multispecies согласно инструкции производителя («IDvet», Франция).

Для оценки серологического статуса у КРС, рожденного и выращенного на территории РФ (аборигенного), в ряде регионов использовали пробы сыворотки крови, отобранные от животных в весенний и осенний периоды. Случаи, когда в таких пробах, отобранных в марте-мае, антитела отсутствовали, но выявлялись в осенний период у ранее серонегативных особей, учитывали как сероконверсию.

Суммарную РНК выделяли из 100 мкл стабилизированной крови с помощью набора QIAamp Viral RNA kit («Qiagen», Германия).

ПЦР в режиме реального времени (ПЦР-РВ) проводили согласно описанному ранее протоколу (2121).

Изолят вируса БШ, выделенного от скота, который был завезен в Калининградскую область из Германии, идентифицировали по сегменту $\mathrm{S}$ с использованием описанных праймеров (24). Первичную нуклеотидную последовательность определяли с прямым и обратным праймером (Applied Biosystems ${ }^{\circledR} 31301$ Genetic Analyzer, «Applied Biosystems, Inc.», США). Нуклеотидные последовательности выравнивали с помощью программы BioEdit (https://softfamous.com/bioedit/), дендрограммы строили в программе MEGA 4 (http://www.megasoftware.net/).

Вирус БШ выделяли из стабилизированной крови. Клетки крови осаждали центрифугированием в течение 10-15 мин при 2000 об/мин, затем ресуспендировали забуферным физраствором (ЗФР, $\mathrm{pH}$ 7,2-7,4) и переосаж- 
дали; процедуру повторяли трижды. Отмытую клеточную фракцию ресуспендировали в стерильном ЗФР, доводя объем до первоначального. В полученных пробах разрушали клетки ультразвуковой вибрацией (Sonopuls HD 3100, «Bandelin electronic GmbH \& Co. KG», Германия) при амплитуде 16-18 мКм (2 раза по 30 с перерывом 60 с). Полученный материал использовали для выделения вируса в перевиваемой культуре клеток почки африканской зеленой мартышки (Vero). Этапы выделения контролировали методом ПЦР-PB.

Клетки выращивали в пластиковых культуральных флаконах («SPL Life Sciences Co., Ltd», Корея) объемом 50 см$^{3}$ до образования монослоя. После этого удаляли ростовую среду (производство ФГБУ ВНИИЗЖ), вносили вируссодержащий материал и инкубировали при $37{ }^{\circ} \mathrm{C} 1$ ч для адсорбции вируса на монослое, затем вносили поддерживающую питательную среду (ППС, производство ФГБУ ВНИИЗЖ). Инфицированную культуру клеток ежедневно просматривали под микроскопом на наличие характерных морфологических изменений. При проявлении цитопатического действия (ЦПД) на 70-80 \% площади монослоя вируссодержащий материал замораживали при температуре $-80{ }^{\circ} \mathrm{C}$. Инфекционную активность вирусного материала определяли микротитрованием в культуре клеток Vero общепринятым методом. Титр вируса вычисляли по Риду и Менчу и выражали как $\lg$ ТЦД $50 / \mathrm{cm}^{3}$. Наличие генома вируса подтверждали методом ПЦР-РВ (21).

Результаты. С 2014 по 2016 год для контроля за распространением вируса БШ проводились мониторинговые исследования проб сывороток крови КРС, отобранных от аборигенного скота из регионов Российской Федерации, а также сыворотки крови от животных, завезенных в Россию из стран ЕС (всего 16749 проб) (табл. 1, 2). Большинство серопозитивных животных выявили в Калининградской, Воронежской и Псковской областях (см. табл. 2).

1. Наличие антител к вирусу болезни Шмалленберга в сыворотке крови у импортированного в Россию крупного рогатого скота (ИФА-тест, 2014 год)

\begin{tabular}{|c|c|c|c|}
\hline \multirow{2}{*}{ Страна-экспортер } & \multirow{2}{*}{ Регион-импортер } & \multicolumn{2}{|r|}{ Число проб } \\
\hline & & всего & серопозитивных, \% \\
\hline Франция & Воронежская область & 522 & 73,9 \\
\hline Германия & Воронежская область, Калининградская область & 137 & 5,8 \\
\hline Чехия & Курская область & 10 & 0 \\
\hline Швеция & Воронежская область, Тюменская область & 160 & 47,5 \\
\hline Венгрия & Калининградская область & 140 & 2,8 \\
\hline Австрия & Воронежская область & 21 & 0 \\
\hline Польша & Республика Татарстан & 74 & 40,5 \\
\hline Дания & Республика Татарстан & 408 & 12,5 \\
\hline Нидерланды & Владимирская область & 53 & 0 \\
\hline Словакия & Калининградская область & 32 & 0 \\
\hline
\end{tabular}

2. Наличие антител к вирусу болезни Шмалленберга в сыворотке крови у российского аборигенного крупного рогатого скота (ИФА-тест)

\begin{tabular}{|c|c|c|c|}
\hline \multirow{2}{*}{ Регион } & \multicolumn{3}{|c|}{ Число проб, всего/положительных } \\
\hline & 2014 год & 2015 год & 2016 год \\
\hline Воронежская область & $1345 / 744$ & Н/И & Н/И \\
\hline Владимирская область & $340 / 0$ & $\mathrm{H} / и$ & н/и \\
\hline Тюменская область & $642 / 263$ & Н/и & Н/и \\
\hline Тверская область & Н/и & $71 / 0$ & Н/и \\
\hline Калининградская область & $2273 / 1488$ & $500 / 297$ & $431 / 163$ \\
\hline Псковская область & $1756 / 368$ & $645 / 196$ & $504 / 50$ \\
\hline Нижегородская область & $1476 / 107$ & Н/и & $443 / 0$ \\
\hline Курская область & $296 / 0$ & $\mathrm{H} / и$ & Н/и \\
\hline Республика Татарстан & $1933 / 63$ & $500 / 63$ & Н/и \\
\hline Республика Дагестан & $457 / 16$ & н/и & Н/и \\
\hline Республика Крым & н/и & $621 / 0$ & н/и \\
\hline Карачаево-Черкесская Республика & $959 / 106$ & $\mathrm{H} / \mathrm{и}$ & Н/и \\
\hline
\end{tabular}


В связи с обнаружением антител против вируса БШ у местного КРС, который был выращен на территории России, в 2015-2016 годах в рамках государственного мониторинга исследовали парных проб сывороток крови у аборигенного поголовья в Калининградской и Псковской областей (см. табл. 3).

3. Наличие антител к вирусу болезни Шмалленберга в парных пробах сыворотки крови (весна-осень) у аборигенного крупного рогатого скота в двух российских регионах (ИФА-тест)

\begin{tabular}{|c|c|c|c|c|c|}
\hline \multirow{3}{*}{ Область } & \multirow{3}{*}{ Район } & \multicolumn{4}{|c|}{ Число проб, всего/положительных } \\
\hline & & \multicolumn{2}{|c|}{2015 год } & \multicolumn{2}{|c|}{2016 год, } \\
\hline & & весна & осень & весна & осень \\
\hline \multirow{7}{*}{ Калининградская } & Славский & $36 / 0$ & $36 / 2$ & $36 / 0$ & $36 / 7$ \\
\hline & Неманский & $36 / 0$ & $36 / 1$ & Н/и & Н/и \\
\hline & Багратионовский & $36 / 0$ & $36 / 7$ & $36 / 0$ & $36 / 10$ \\
\hline & Нестеровский & $36 / 0$ & $36 / 0$ & $36 / 0$ & $36 / 0$ \\
\hline & Правдинский & $36 / 0$ & $36 / 0$ & $72 / 0$ & $72 / 17$ \\
\hline & Краснознаменский & н/и & н/и & $36 / 0$ & $36 / 9$ \\
\hline & Озерский & $\mathrm{H} / \mathrm{и}$ & н/и & $36 / 0$ & $36 / 0$ \\
\hline \multirow{6}{*}{ Псковская } & Красногородский & $32 / 0$ & $32 / 2$ & $36 / 0$ & $36 / 0$ \\
\hline & Себежский & $55 / 0$ & $55 / 2$ & $36 / 0$ & $36 / 12$ \\
\hline & Палкинский & $55 / 0$ & $55 / 1$ & н/и & н/и \\
\hline & Усвятский & н/и & Н/и & $36 / 0$ & $36 / 2$ \\
\hline & Куньинский & Н/и & Н/и & $36 / 0$ & $36 / 0$ \\
\hline & Дедовичский & Н/и & Н/и & $36 / 0$ & $36 / 0$ \\
\hline
\end{tabular}

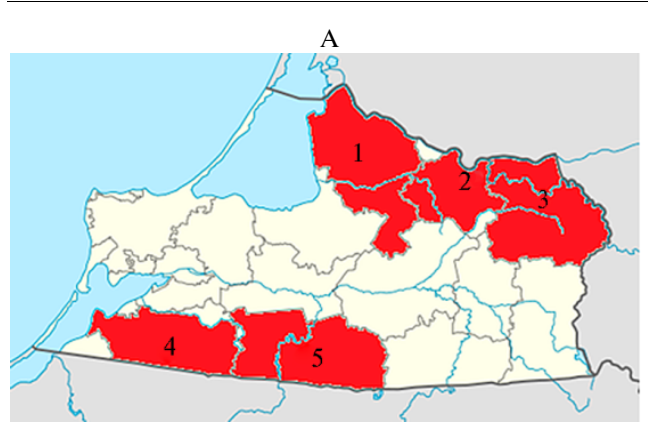

Рис. 1. Регионы Калиниградской (А) и Псковской (Б) областей с выявленной сероконверсией по вирусу болезни Шмалленберга: 1 - Славский, 2 - Неманский, 3 - Краснознаменский $4-$ Багратионовский, 5 - Правдинский $6-$ Палкинский, 7 - Красногородский, 8 - Дедовичский, $9-$ Себежский, $10-$ Усвятский (20152016 годы).

При весенне-осеннем исследовании парных проб сывороток крови от животных из Калининградской области в 2015 году выявили антите-

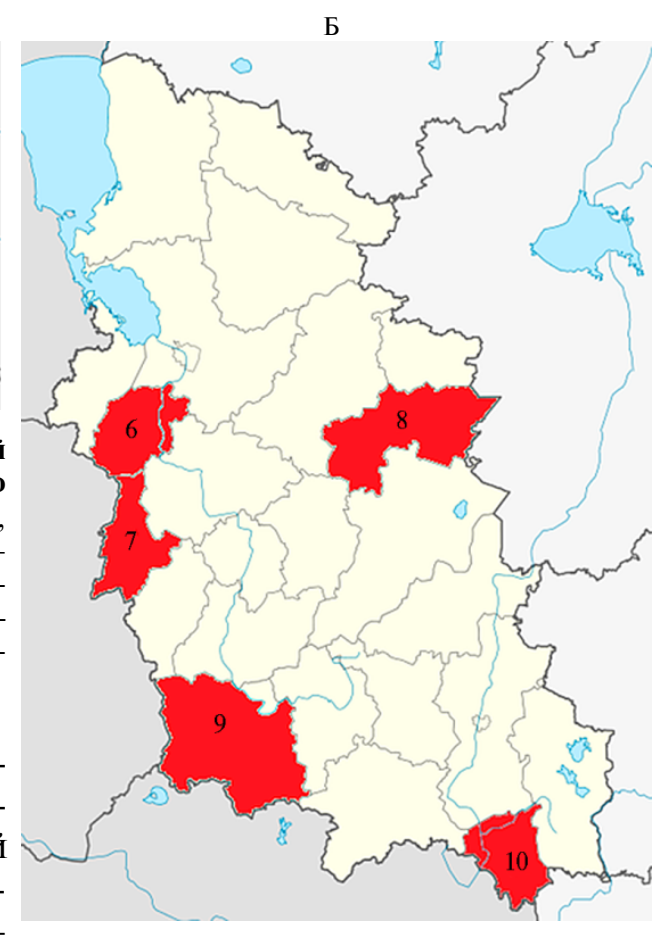
ла к вирусу БШ у 10, в 2016 году у 34 особей, в Псковской области соответственно у 5 и 14 животных. В каждой из областей сероконверсию наблюдали в 5 районах (рис. 1).

При выделении вируса БШ в культуре клеток Vero, цитопатические изменения регистрировали на 4-м пассаже через 96 ч после инокуляции. Цитопатическое действие вируса в культуре клеток Vero первоначально проявлялось как образование псевдо-синцития со слиянием наружных мембран клеток, в дальнейшем происходило их округление и слияние в 
конгломераты. С увеличением числа пассажей проявление ЦПД регистрировали через 48 ч культивирования (рис. 2).

Флаконы с зараженной культурой клеток каждого пассажа замораживали, оттаивали и определяли инфекционную активность вируса в культуре клеток Vero. Титр инфекционной активности составлял на 5-м пассаже

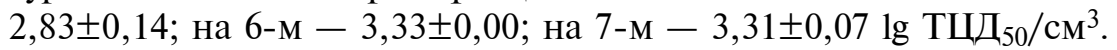
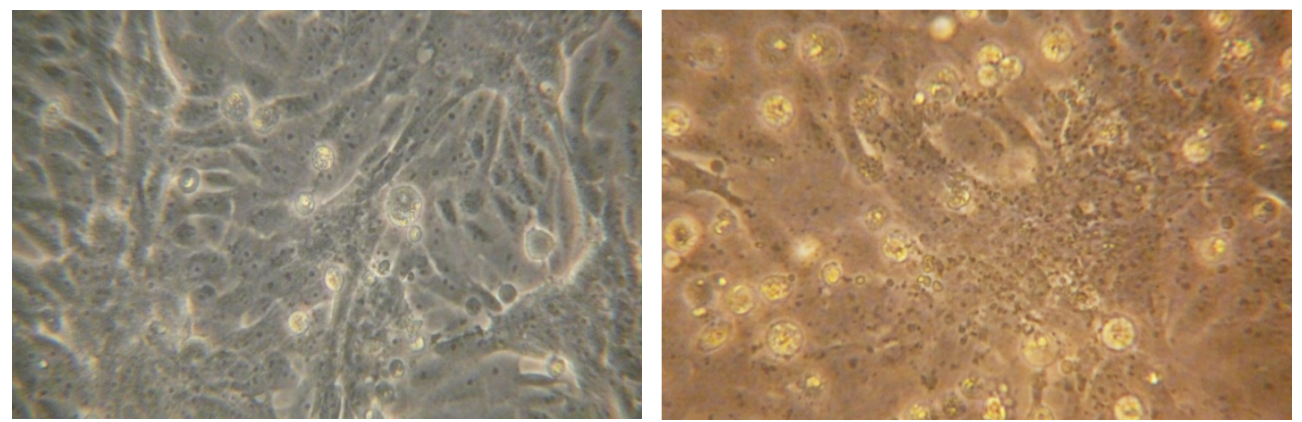

Рис. 2. Монослой 2-суточной незараженной культуры клеток Vero (слева) и клетки через 48 ч после инфицирования вирусом болезни Шмалленберга (справа). Световая микроскопия (микроскоп Olympus, Япония).

Для подтверждения видовой принадлежности изолятов амплифицировали фрагмент сегмента S длиной 256 п.н., кодирующий нуклеокапсидный протеин (24) (рис. 3). Проведенный филогенетический анализ показал, что изолят вируса БШ Калининград/2016 (диагностический) обладает $100 \%$ гомологией с изолятами вируса БШ, выявленными в странах Северной Европы (см. рис. 3) (изолят депонирован в коллекции штаммов ФГБУ ВНИИЗЖ).

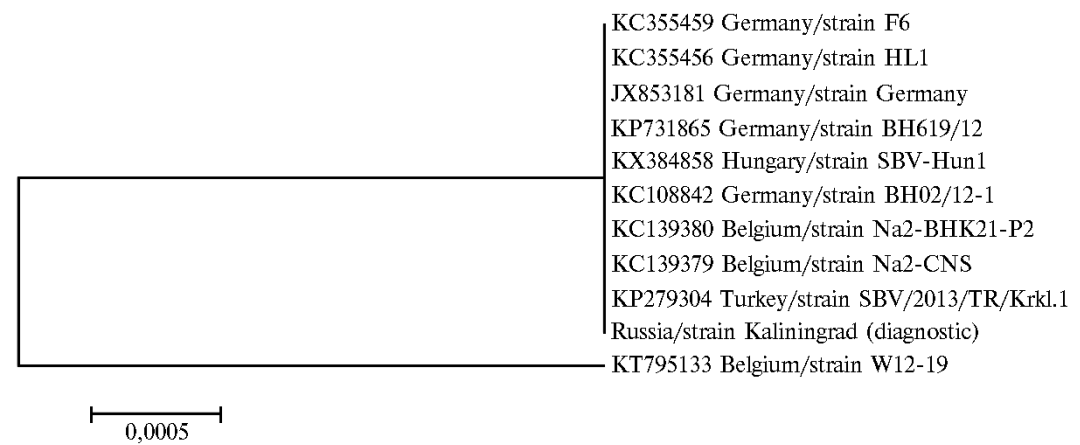

Рис. 3. Филогенетическое положение изолята вируса болезни Шмалленберга Калининград/2016 (диагностический). Дендрограмма построена на сравнении нуклеотидных последовательностей фрагмента 256 п.н. S сегмента генома.

Также в период с 2015 по 2017 год исследовали образцы крови крупного рогатого скота на наличие генома вируса БШ. Геном этого возбудителя был обнаружен в трех из 33542 проанализированных проб у скота, импортированного из Германии и Венгрии в 2016-2017 годах. Исследованию подвергался в основном скот, завезенный из Нидерландов, Германии, Чехии, Венгрии, Словакии, Франции, а также КРС местного происхождения.

Со времени регистрации вируса БШ на территории ряда стран ЕС в 2012 году $(1,7)$ в РФ существовала проблема возможного заноса этого патогена с племенным скотом. Особенность течения инфекции заключается в незначительной по продолжительности виремии (3-5 сут) (7), что существенно снижает шансы детекции генома вируса у больных животных 
при прижизненной диагностике (4). В связи с отсутствием обязательной нотификации БШ в ЕС оценивать риски завоза этой инфекции на территорию нашей страны практически невозможно из-за распространения вируса в странах ЕC.

Ситуация с распространением БШ обусловлена прежде всего отсутствием должного внимания к проблеме со стороны ветеринарных и фитосанитарных служб стран Европы, несмотря на масштабы распространения заболевания в этих странах и мнение специалистов Европейского агентства по безопасности продуктов питания (European Food Safety Authority - EFSA), что без проведения мониторинга и обязательной нотификации новых случаев БШ невозможно оценить благополучие страны по указанному заболеванию. Представители ЕС продолжают утверждать, что болезнь не наносит значительного экономического ущерба и не представляет риска для животноводства. На основании этого страны ЕС не проводят транспарентные мониторинговые исследования, а в случае выявления инфекции страна ограничивается признанием своей территории эндемичной (15).

Результаты исследований европейских ученых свидетельствуют о том, что с момента прекращения массового распространения вируса БШ он прочно закрепился на территории ЕС (15, 25-27). В Ирландии в молочных стадах с 3 по 10 марта 2017 года были выявлены антитела к этому вирусу в общей сложности у 256 животных. Рост серопревалентности также отмечался в период с июня по сентябрь 2016 года в бельгийской популяции овец (15).

Российская Федерация - основной торговый партнер ряда стран ЕС по импорту племенного КРС. Более того, через Российскую Федерацию происходит транзит животных в Казахстан и другие государства. Поскольку главными переносчиками вируса БШ служат мокрецы рода Culicoides, которые распространены на всей территории России, согласно обзорам энтомофауны РФ и анализу ситуации о возможном распространении БШ переносчиками (6), это может потенциально служить фактором распространения вируса на территории РФ.

Серологические исследования в ряде регионов РФ (см. табл. 1) показали, что аборигенный скот серопозитивен по вирусу БШ, однако согласно официальной статистике никаких признаков врожденных уродств у телят не отмечалось. Для исключения ошибки среди местного (аборигенного) скота Калининградской и Псковской областей провели анализ парных проб сывороток крови от животных, отобранных в весенний и осенний периоды. Результаты показали циркуляцию вируса среди поголовья без проявления клинических признаков инфекции (см. табл. 3), что свидетельствует о необходимости проведения в указанных регионах энтомологических исследований проб биоматериала при клинических случаях проявления тератогенного эффекта у стельных животных. Наибольшее число серопозитивных аборигенных животных обнаружили в Калининградской, Псковской и Воронежской областях, в районах, граничащих со странами ЕС. Возможно, что циркулирующий вирус в приграничных неблагополучных странах активно заносится с переносчиками на территорию РФ или уже закрепился в перечисленных регионах. Важно отметить, что результаты работ ученых из стран ЕС $(15,26,27,2828)$ свидетельствует о том, что БШ, возможно, стала эндемичной в Европе.

Антитела против вируса БШ также выявлены у КРС в Республике 
Дагестан (см. табл. 2). Вероятно, вирус проник на территорию республики из прилегающих государств (например, Турции), которые сообщали о распространении БШ на своей территории (27). Сейчас появляются многочисленные данные о распространении вируса БШ за пределы Европы и Кавказа. Так, в Эфиопии и Мозамбике выявлено массовое распространение этого возбудителя среди КРС $(2829,30)$. Более того, антитела к вирусу БШ выявлены также у КРС в Китае (3131).

При исследовании сывороток крови на наличие генома вируса БШ он был выявлен у скота, завезенного из Венгрии и Германии на территорию Калининградской и Тюменской областей. Обнаружение антител и генома вируса БШ у скота показывает, что этот возбудитель уже циркулирует на территории РФ и представляет собой серьезную угрозу при дальнейшем распространении.

Сегмент S у выделенного изолята Калининград/2016 оказался на $100 \%$ гомологичен S сегменту изолятов вируса БШ, выявленных в Европе (см. рис. 5). Вирус БШ характеризуется высокой генетической стабильностью несмотря на то, что его геном представлен одноцепочечной РНК. Ранее было установлено (32), что изоляты вируса БШ, выявленные в Венгрии, имели 99,3\% нуклеотидной гомологии. Группа ученых из Турции также обнаружила, что вирус БШ по сегменту S был идентичен изоляту из Германии и Бельгии (одна нуклеотидная замена) (24).

Итак, в результате проведенных исследований впервые со времени регистрации вируса болезни Шмалленбера (БШ) в ЕС сообщается о выявлении сероконверсии по этому возбудителю у аборигенных животных в регионах России, граничащих с неблагополучными по БШ странами ЕС, что, возможно, свидетельствует о заносе и неконтролируемом распространении вируса на территории РФ. Более того, вывод о том, что вирус мог быть занесен ранее как с импортными животными, так и с переносчиками, подтверждается выявлением ПЦР-позитивных животных, импортируемых из ЕС. Секвенирование сегмента $\mathrm{S}$ у выделенного нами вирусного изолята показало, что он идентичен изолятам вируса БШ, циркулирующим в странах ЕС. Однозначный ответ может быть получен при энтомологических исследованиях и выявлении генома вируса БШ в кровососущих насекомых-переносчиках. Поэтому далее мы планируем изучение потенциальных переносчиков, которые поддерживают персистенцию вируса на территории районов, где выявлены случаи сероконверсии у животных, рожденных и выращенных в России, в том числе полученных от импортного скота.

\section{ЛИТЕРАТУРА}

1. Hoffmann B., Scheuch M., Höper D., Jungblut R., Holsteg M., Schirrmeier H., Eschbaumer M., Goller K.V., Wernike K., Fischer M., Breithaupt A., Mettenleiter T.C., Beer M. Novel orthobunyavirus in cattle, Europe, 2011. Emerg. Infect. Dis., 2012, 18: 469-472 (doi: 10.3201/eid1803.111905).

2. Yanase T., Kato T., Aizawa M., Shuto Y., Shirafuji H., Yamakawa M., Tsuda T. Genetic reassortment between Sathuperi and Shamonda viruses of the genus Orthobunyavirus in nature: implications for their genetic relationship to Schmallenberg virus. Arch. Virol., 2012, 157: 16111616 (doi: 10.1007/s00705-012-1341-8).

3. Muskens J., Smolenaars A.J., Van der Poel W.H., Mars M.H, van Wuijckhuizen L., Holzhauer M., van Weering H., Kock P. Diarree en productiedaling op Nederlandse melkbedrijven door het Schmallenbergvirus. Tijdschr. Diergeneeskd., 2012, 137: 112-115.

4. Колбасов Д., Сальников Н., Никитина Е., Луницин А. Вирус болезни Шмалленберг: 
пути заражения и диагностика. Животноводство России, 2012, 11: 35-36.

5. Глухова В.М. Фауна СССР. Насекомые двукрылые. Л., 1989.

6. Спрыгин А.В., Федорова О.А., Бабин Ю.Ю., Кононов А.В., Караулов А.К. Мокрецы рода Culicoides (Diptera:Ceratopogonidae) и их роль в распространении блютанга и болезни Шмалленберга в России (обзор). Сельскохозяйственная биология, 2015, 50(2): 183-197 (doi: 10.15389/agrobiology.2015.2.183rus).

7. Спрыгин А.В., Кононов А.В., Бабин Ю.Ю., Мищенко В.А. Болезнь Шмалленберга: молекулярно-биологические особенности и клиническая картина (обзор). Сельскохозяйственная биология, 2012, 6: 24-34 (doi: 10.15389/agrobiology.2012.6.24rus).

8. Barber J., Harrup L.E., Silk R., Veronesi E., Gubbins S., Bachanek-Bankowska K., Carpenter S. Blood-feeding, susceptibility to infection with Schmallenberg virus and phylogenetics of Culicoides (Diptera:Ceratopogonidae) from the United Kingdom. Parasites \& Vectors, 2018, 11(1): 116 (doi: 10.1186/s13071-018-2650-x).

9. De Regge N. Akabane, Aino and Schmallenberg virus - where do we stand and what do we know about the role of domestic ruminant hosts and Culicoides vectors in virus transmission and overwintering? Curr. Opin. Virol., 2017, 27: 15-30 (doi: 10.1016/j.coviro.2017.10.004).

10. Pagus N., Talavera S., Verdún M., Pujol N., Valle M., Bensaid A., Pujols J. Schmallenberg virus detection in Culicoides biting midges in Spain: first laboratory evidence for highly efficient infection of Culicoides of the Obsoletus complex and Culicoides imicola. Transbound. Emerg. Dis., 2018, 65(1): 1-6 (doi: 10.1111/tbed.12653).

11. Rasmussen L.D., Kristensen B., Kirkeby C. Culicoides as vectors of Schmallenberg virus. Emerg. Infect. Dis., 2012, 18: 1204-1206 (doi: 10.14202/vetworld.2018.30-33).

12. Elliott R.M., Blakqori G. Molecular biology of orthobunyaviruses. In: Bunyaviridae: molecular and cellular biology /A. Plyusnin, R.M. Elliott (eds.). Norfolk, UK, 2011: 1-39.

13. Saeed M.F., Li L., Wang H., Weaver S.C., Barrett A.D. Phylogeny of the Simbu serogroup of the genus Bunyavirus. J. Gen. Virol., 2001, 82(9): 2173-2181 (doi: 10.1099/0022-1317-82-9-2173).

14. Kęsik-Maliszewska J., Larska M. Detection of Schmallenberg virus RNA in bull semen in Poland. Pol. J. Vet. Sci., 2016, 19(3): 655-657 (doi: 10.1515/pjvs-2016-0083).

15. Sohier C., Deblauwe I., VanLoo T., Hanon J.B., Cay A.B., DeRegge N. Evidence of extensive renewed Schmallenberg virus circulation in Belgium during summer of 2016 - increase in arthrogryposis-hydranencephaly cases expected. Transbound. Emerg. Dis., 2017, 64(4): 1015-1019 (doi: 10.1111/tbed.12655).

16. Beer M., Conraths F.J., van der Poel W.H. 'Schmallenberg virus' - a novel orthobunyavirus emerging in Europe. Epidemiology and Infection, 2013, 141(1): 1-8 (doi: 10.1017/S0950268812002245).

17. Byadovskaya O.P., Zimina E.E., Piskunov A.V., Babin Y.Y., Sprygin A.V., Kononov A.V. Serological surveillance of Schmallenberg virus infection in local and import cattle in the Russian Federation. Proc. Int. Conf. «Primed for tomorrow», Denmark. Copenhagen, 2014: 6.

18. Эпизоотическая ситуация: информационное сообщение № 84 от 29.04.2014 г. Информационно-аналитический центр Россельхознадзора (электронный ресурс). Режим доступа: http://www.fsvps.ru/fsvps/iac/messages/1554.html. Без даты.

19. Эпизоотическая ситуация: информационное сообщение № 58 от 9.04.2013 г. Информационно-аналитический центр Россельхознадзора (электронный ресурс). Режим доступа: http://www.fsvps.ru/fsvps/iac/messages/1271.html. Без даты.

20. Эпизоотическая ситуация: информационное сообщение № 224 от 23.10.2014 г. Информационно-аналитический центр Россельхознадзора (электронный ресурс). Режим доступа: http://www.fsvps.ru/fsvps/iac/messages/1222.html. Без даты.

21. Bilk S., Schulze C., Fischer M., Beer M., Hlinak A., Hoffmann B. Organ distribution of Schmallenberg virus RNA in malformed newborns. Vet. Microbiol., 2012, 159(1-2): 236-238 (doi: 10.1016/j.vetmic.2012.03.035).

22. OIE. Manual of diagnostic tests and vaccines for Terrestrial animals 2018 (электронный ресурс). Режим доступа: http://www.oie.int/en/international-standard-setting/terrestrial-manual/accessonline/. Без даты.

23. Zentis H.J., Zentis S., Stram Y. Schmallenberg virus: lessons from related viruses. Vet. Rec., 2012, 171(8): 201-202 (doi: 10.1136/vr.e5653).

24. Yilmaz H., Hoffmann B., Turan N., Cizmecigil U.Y., Richt J.A., Van der Poel W.H. Detection and partial sequencing of Schmallenberg virus in cattle and sheep in Turkey. Vector-Borne and Zoonotic Diseases, 2014, 14(3): 223-225 (doi: 10.1089/vbz.2013.1451).

25. Collins Á.B., Barrett D.J., Doherty M.L., McDonnell M., Mee J.F. Significant re-emergence and recirculation of Schmallenberg virus in previously exposed dairy herds in Ireland in 2016. Transbound. Emerg. Dis., 2017, 64(5): 1359-1363 (doi: 10.1111/tbed.12685).

26. Gache K., Zientara S., Collin E., Authié E., Dion F., Garin E., Zanella G., Calavas D. Spatial and temporal patterns of Schmallenberg virus in France in 2016. Vet Rec., 2018, 182(20): 575 (doi: 10.1136/vr.104769). 
27. Azkur A.K., Albayrak H., Risvanli A., Pestil Z., Ozan E., Y1lmaz O., Tonbak S., Cavunt A., Kadı H., Macun H.C., Acar D., Özenç E., Alparslan S., Bulut H. Antibodies to Schmallenberg virus in domestic livestock in Turkey. Trop. Anim. Health. Prod., 2013, 45(8): 1825-1828 (doi: 10.1007/s11250-013-0415-2).

28. Hoffmann B., Schulz C., Beer M. First detection of Schmallenberg virus RNA in bovine semen, Germany. Vet. Microbiol., 2013, 167(3-4): 289-295 (doi: 10.1016/j.vetmic.2013.09.002).

29. Blomstrцm A.L., Stenberg H., Scharin I., Figueiredo J., Nhambirre O., Abilio A.P., Fafetine J., Berg M. Serological screening suggests presence of Schmallenberg virus in cattle, sheep and goat in the Zambezia Province, Mozambique. Transbound. Emerg. Dis., 2014, 61(4): 289-292 (doi: 10.1111/tbed.12234).

30. Sibhat B., Ayelet G., Gebremedhin E.Z., Skjerve E., Asmare K. Seroprevalence of Schmallenberg virus in dairy cattle in Ethiopia. Acta Tropica, 2018, 178: 61-67 (doi: 10.1016/j.actatropica.2017.10.024).

31. Zhai S.L., Lv D.H., Wen X.H., Zhu X.L., Yang Y.Q., Chen Q.L., Wei W.K. Preliminary serological evidence for Schmallenberg virus infection in China. Trop. Anim. Health Prod., 2018, 50(2): 449-453 (doi: 10.1007/s11250-017-1433-2).

32. Fehér E., Marton S., Tyth Á.G., Ursu K., Wernike K., Beer M., Dán Б., Bányai K. Sequence analysis of Schmallenberg virus genomes detected in Hungary. Acta Microbiologica et Immunologica Hungarica, 2017, 64(4): 373-384 (doi: 10.1556/030.64.2017.038).

\title{
ФБГУ Федеральный центр охраны
} здоровья животных, 600901 Россия, г. Владимир, мкр. Юрьевец, ФГБУ ВНИИЗЖ,

\section{DETECTION OF SCHMALLENBERG VIRUS IN CATTLE IMPORTED INTO THE RUSSIAN FEDERATION}

\author{
O.G. Gubenko, O.P. Bjadovskaya, A.V. Sprygin, S.V. Kononova, A.V. Piskunov, \\ A.V. Kononov
}

Federal Center for Animal Health Control, FGBU VNIIZZh, mkr. Yurievets, Vladimir, 600901 Russia, e-mail spriginav@mail.ru ( $\square$ corresponding author), pestova@arriah.ru, kostrova@arriah.ru, kononova@arriah.ru, bjadovskaya@arriah.ru, zhbanova@arriah.ru,kononov@arriah.ru ORCID:

Gubenko O.G. orcid.org/0000-0001-9252-9064

Byadovskaya O.P. orcid.org/0000-0002-8326-7151

Sprygin A.V. orcid.org/0000-0001-5982-3675

The authors declare no conflict of interests

Received December 27, 2018
Kononova S.V. orcid.org/0000-0002-3932-2416

Piskunov A.V. orcid.org/0000-0002-2805-5009

Kononov A.V. orcid.org/0000-0002-5523-3261

doi: 10.15389/agrobiology.2019.6.1247eng

Abstract

Schmallenberg disease, a transmissive vector-borne arbovirus infection affecting cattle, sheep and goats of all age groups, which may lead to significant economic losses. In the Russian Federation, specific antibodies against the causative agent of Schmallenberg disease were first detected in April 2013 and 2014 in the Andreapolsky and Konakovsky districts of the Tver region. In October 2014, specific antibodies were detected in cattle blood in one of the farms of the Novosokolnichesky district of the Pskov region. In this study we provide an overview of the serological and molecular surveillance for Schmallenberg virus (SBV) in the Russian Federation in 2014-2016. Testing of serum samples from cattle born and raised in regions sharing border with previously affected EU countries demonstrated seroconvertion in sentinel animals. The current findings raise concerns with regard to a possible SBV distribution and circulation in Russian cattle. We for the first time report the detection and isolation of SBV in cattle imported into Russia from EU. The virus was isolated on Vero cells and sequenced. The $\mathrm{S}$ gene sequence analysis showed $100 \%$ identity of the recovered SBV strain to those isolated in Northern Europe in 2012.

Keywords: Schmallenberg virus (SBV), continuous Vero cell culture, polymerase chain reaction (PCR), phylogenetic analysis, sequencing. 